Dokuz Eylül Üniversitesi-Mühendislik Fakültesi

Fen ve Mühendislik Dergisi

Cilt 19, Sayı 57, Eylül 2017
Dokuz Eylul University-Faculty of Engineering Journal of Science and Engineering Volume 19, Issue 57, September 2017

DOI: $10.21205 /$ deufmd.2017195789

\title{
Şehir İçi Tünel İnşaatlarındaki Kazılarda Patlatma Tasarımı ve Titreşim Modellemesi
}

\author{
Kerim KÜÇÜK*1, C.Okay AKSOY ${ }^{1}$
}

1Dokuz Eylül Üniversitesi, Mühendislik Fakültesi, Maden Müh. Bölümü, 35390, İzmir

(Alınıș / Received: 13.07.2017, Kabul / Accepted: 16.08.2017, Online Yayınlanma / Published Online: 20.09.2017)

\begin{abstract}
Anahtar Kelimeler
Özet: Günümüzde şehir içi ulaşımı rahatlatmaya yönelik yapılan tünel inşaatlarındaki kazı yöntemleri, tünelin uzunluğu, tünel

Tünel Kazısı, Patlatma Tasarımı Titreşim, Modelleme, güzergâhının geçtiği jeolojik birimler...vb. parametrelere göre belirlenmektedir. Çift tüp olarak yaklaşık 1645 m uzunlukta açılan Konak Tünellerinde Yeni Avusturya Tünel Açma (NATM) yöntemi uygulanmış olup, tünel güzergahı Yeşildere caddesi girişinden itibaren başlayıp, 2. Kadriye mahallesi, 1. Kadriye mahallesini takiben Namık Kemal mahallesinden sonra Eğitim Diş Hastanesi ile Etnoğrafya Müzesi arasında son bulmaktadır. Bu çalışmada, İzmir Konak tünelleri inşaatında, patlatmalı kazı sırasında arzu edilen teknik sonuçların ekonomik ve emniyetli limitlerde kalması, patlatmadan kaynaklanan titreșim ve hava șoku gibi çevresel problemlerin en aza indirilmesine izin veren bir yaklașımla patlatma ön tasarımı yapılmıștır.
\end{abstract}

\section{Blasting Design and Vibration Modelling in Urban Tunnel Excavations}

\section{Keywords}

Tunnel Excavation Blasting Design, Vibration, Modelling,

\begin{abstract}
Today, tunnels constructions designed to relieve inner city transportation and tunnel excavation methods determined by the length of the tunnel, the geological units through the tunnel route, etc.

The New Austrian Tunneling (NATM) method has been applied in Konak Tunnels, which is opened as a double tube in a length of approximately $1645 \mathrm{~m}$. The tunnel route starts from the entrance of Yeşildere Caddesi and after the 2nd Kadriye neighborhood, 1st Kadriye district, Namık Kemal district and then between Education Dental Hospital and Etnography Museum End.

In this study, preliminary Blasting design was carried out in İzmir Konak tunnels with an approach that allowed the technical results to remain at economical and safe limits during the explosive excavation, minimizing environmental problems such as vibration and air pollution caused by detonation.
\end{abstract}




\section{GíRiş}

Günümüzde yol, baraj, tünel, madencilik, inşaat, alt yapı vb. gibi kazı gerektiren mühendislik projelerinde sıklıkla uygulanan patlatma; kaya kütlesini patlayıcı yardımı ile kontrollü bir şekilde parçalama işlemidir. Patlatmalı kazı hızlı ve ekonomik bir yöntem olmasına rağmen, yerleșim yerlerinin yakınlarında yapilan kontrolsüz patlatmalar bazen çevresel problemlere (hava şoku, gürültü, titreşim, kaya fırlaması, psikolojik rahatsızlıklar...vb.) neden olabilmektedir.

Patlatma kaynaklı sarsıntıların çevre yerleşim yerlerine olan etkilerinin belirlenmesi ve minimize edilmesinde alışlagelmiş yöntem, sismografla en yüksek parçacık hızlarının belirlenmesi, patlatma ile ölçüm alınan yer arasındaki güzergah için arazi katsayılarının saptanması, sarsıntının yayılma kuralını belirleyen ampirik formülün bulunması ve bu formül kullanılarak yapılan patlatmalar için mesafeye bağlı olarak bir seferde güvenle ateşlenebilecek en yüksek patlayıcı madde miktarlarının saptanmasıdır [1-14]

Ekonomik ve emniyetli bir patlatma tasarımı ile patlatma kaynaklı çevresel problemlerini minimuma indirmek mümkündür. Optimum bir patlatma tasarımının temel şartı kaya, patlayıcı, delik geometrisi ve patlatma sonucundan beklentilerin toplu halde tasarıma dahil edilmesidir. Günümüzde patlatma kaynaklı sorunların çevre yerleşim yerlerine olan etkilerinin belirlenmesi ve minimize edilmesinde uygulanan en yaygın yöntem, sismografla en yüksek parçacık hızlarının ölçülmesi, patlatma ile ölçüm alınan yer arasındaki güzergah için arazi katsayılarının belirlenmesi, sarsıntının yayılma kuralını belirleyen ampirik formülün bulunması ve bu formül kullanılarak belirli bir parçaçı hızı değeri için mesafeye bağlı olarak herhangi bir gecikme aralı̆̆ında kullanılabilecek en fazla patlayıcı madde miktarını önceden belirlemek ve kontrollü patlatmalar gerçekleștirmektir. [1-15]

Elde edilen ampirik formül sayesinde patlatmaların tamamının izlenmesine (titreşim ve gürültü ölçümü alınması vb.) gerek kalmayabilir. Ancak üretilen ampirik formüller bir yaklaşım sağlamakla birlikte, belirli bir mesafe ve patlayıcı madde kullanımı için arazide ne kadar titreșim oluşacağına yönelik her zaman \%100 doğruluk sağlamaz. Ayrıca bu ampirik formüllerin büyük çoğunluğu arazinin jeolojik yapısına bağlı olarak değișen frekansı göz önüne almamaktadır. $\mathrm{Bu}$ nedenle özellikle hassas yerlerde (yapı birimlerine çok yakın yerler, heyelan riski bulunan yerler vb.) yapılan kazı çalışmalarda patlatma kaynaklı çevresel sorunları minimize etmenin/azaltmanın en doğru yolu, patlatma tasarımı ve çevresel etkileri konusunda uzman kişilerce patlatmaların tamamının izlenmesi ve gerektiğinde patlatma tasarımında değişiklikler yapılarak kazı çalışmalarının emniyetli ve ekonomik bir şekilde tamamlanmasına katkı sağlanılmasıdır.

$\mathrm{Bu}$ çalıșmanın amacl, İzmir Konak tünelleri inşaatında, patlatmalı kazı sırasında istenilen teknik sonuçların ekonomik ve emniyetli limitlerde kalması, patlatmadan kaynaklanan titreşim ve hava şoku gibi çevresel problemlerin en aza indirilmesine izin veren bir yaklaşımla patlatma ön tasarımı yapılmasıdır.

\section{TÜNEL PATLATMALARI VE HASAR KRITTERLERI}

Tünel patlatmaları, basamak patlatmalarına kıyasla daha karmaşık bir işlemdir. Başlangıçtaki kırılmayı karşılayabilecek tek serbest yüzey tünel yüzeyidir. Tünel patlatmalarında alanın sınırlı ve dar olması nedeniyle, delik çapları küçülmekte ve basamak 
patlatmasına kıyasla oldukça yüksek spesifik yük oluşmaktadır.

Teknolojik gelişmelere ve nüfus artışına paralel olarak trafik ve ulaşım sorununu çözmek vb. amaçlarla özellikle büyük şehirlerde tünel yapımı giderek artmaktadır. Patlatmalı kazı yönteminin uygulandığı tünel kazılarında özellikle yerleşim birimlerine yakın mesafelerde bazı çevresel problemlerle (titreşim ve gürültü kaynaklı şikayetler, yapısal hasar oluşumu vb) karşılaşılmaktadır. Ekonomik ve emniyetli bir patlatma, ayn zamanda bu tür sorunları en aza indiren bir patlatmadır. Bu durum, ancak doğru bir patlatma tasarımı ve çevresel etkilerinin izlenmesi ile gerçekleştirilebilir.

Patlatma kaynaklı titreşimlerin yüzey yapılarına etkisi bir çok araştırmacı tarafından araştırılmıştır $[24,25,26,27$, $28,29,31]$. Tünel patlatmalarında, aşırı açılmaların, tünel çevresinde kırılma ve çatlamaların önlenmesi, tünel kazı arınına yakın olarak yerleştirilen saplama ve püskürtme betonun patlatma sonucu oluşan titreşimlerden zarar görmemesi için her bir kaya sınıfında farklı patlatma paterni ve delik şarjları kullanılmaktadır [32]

Yeraltı tünel patlatmalarında aşırı açılmayı önlemek için;

1. Çevre deliklerinde delik aralıklarının azaltılması,

2. Çevre deliklerinde şarj miktarlarının azaltılması

3. İnfilaklı fitilin ( $\left.80 \mathrm{gr} / \mathrm{m}^{\prime} l i k\right)$ doğrudan uygulanması,

4. Çevre deliklerinin daha küçük çaptaki kapsüle duyarlı patlayıcılarla şarj edilmesi,

5. Çevre deliklerinin bir dolu bir boş şarj edilmesi,

gibi bazı özel uygulamalar

bulunmaktadır.

\subsection{Patlayıcı Seçimi}

Tünel patlatmalarında Tünel patlatmalarında son 15 yıldır, emulsiyon patlayıcılar, nitrogliserin esaslı patlayıcıların yerini almıştır. Ayrıca son zamanlarda harç tipi, ve emülsiyon tipi patlayıcıların da kullanılmaya başlandığı görülmektedir.

Tünel patlatmalarında delikler, özellikle kesme bölgesinde birbirine çok yakın delinmektedir. Gerekli önlemler alınmadığı takdirde;

- Birbirine yakın deliklerde bir önceki sırada patlayan delik, bir sonraki sırada patlatması gereken deliği, sirayet patlaması yolu ile ateşleyebilmektedir. $\mathrm{Bu}$ da roundun gecikme paterni bozulduğu için kötü sonuç alınmasına yol açmaktadır.

- Birbirine yakın deliklerde bir önceki sırada patlayan delik, bir sonraki sırada patlatması gereken delikteki patlayıcı maddeyi (özellikle toz patlayıcı ise) sıkıştırarak yoğunluğunun artmasına, patlamaya duyarlılığının azalmasına yol açmakta dolayısı ile bazı delikler patlamamakta ve yine patern bozulmaktadır.

- Kesme bölgesinde deliklerin çok yakın olması ve milisaniye aralıklar kullanılması nedeni ile, gereğinden kuvvetli veya yüksek konsantrasyonda patlayıcı madde kullanılır ise, kesme bölgesindeki kaya yapısında kilitlenme meydana gelmektedir.

Tüm bu olayların önüne geçebilmek için, öncelikle gereğinden kuvvetli patlayıcı madde kullanılmaması gerekmektedir.

\subsection{Delik Boyu ve Delik Çapı}

Pratikte bir tünelde, kesit genişliğinin $2 / 3$ ünden fazla ilerleme hedeflenmemesi gerekmektedir. Çevreye verilen sarsıntı açısından bir sınırlandırma söz konusu ise, yine patlayıcı maddeyi azaltmak amacı ile, 
ilerleme miktarı kısa tutulmalıdır. Bazı zayıf kaya yapılarında, kayacın taşıma kapasitesi düşük olabilmekte ve ilerleme boyunun buna göre saptanması hayati önem taşımaktadır.

Tünel kesiti bilindikten, özgül şarj saptandıktan sonra geriye kalan iş, patlayıcı maddenin aynada geometrik olarak dağıtılmasıdır. Bunu belirleyen parametre delik çapıdır. Küçülen delik çapı ile maliyet düşmekte, büyüyen delik çapı ile maliyet artmaktadır.

Büyük tünel projelerinde delik çapının saptanmasinda bazı parametreler rol oynar. Piyasada mevcut dinamit kartuş çapı gözetilmelidir. Tapalar ile kartuşları delik içinde sıkılama işlemi hem önerilen bir yol değildir, hem de işçilik bakımından kayıplara neden olabilen bir şekildir. Yine ülkemizde görülen bir handikap da kartuşların kağıdıdır. Batı ülkelerinde, ufak dinamit kartuşların, büyük çaplı deliklere istenen yoğunlukta doldurabilmek için şarj cihazları kullanılmaktadır. Bu cihazların delik içine giren nozulun uç kısmında bıçaklar vardır. Buradan hızla geçen kartuşun kağıda kesilir ve delik dibine vurduğunda şişerek deliği tamamına yakın doldurur. Ama yerli üretim üzerindeki kağıt buna olanak vermemiştir. Yüksek tempolu projelerde en gerçekçi çözüm, mevcut kartuş çapına göre delik çapı seçilmesidir [33].

Tünel kesitinin büyük olmasına karşın, çevreye verilen sarsıntının sınırlandırılması, tünel duvarına minimum zarar verilmesi gerektiğinde, şarj yoğunluğunun, dolayısı ile delik çapının küçük tutulması gerekmektedir.

\subsection{Titreşim Ölçütleri}

Patlatma ile çevreye verilen olumsuzlukların en önemlisi yer titreşimleridir. Yer titreşimleri depreme benzer etkiler yapmaktadır. Dolayısı ile oluşan yapı hasarları benzerlik göstermektedirler. Patlatma ile oluşan titreşimler, taşıdıkları enerji düzeyinde hasara neden olmaktadırlar.

Titreșimlerin enerji düzeyleri; parçacık yer değiştirmesi $(\mathrm{mm})$, parçacık hızı $(\mathrm{mm} / \mathrm{s})$, parçacık ivmesi $\left(\mathrm{mm} / \mathrm{s}^{2}\right)$ ve dalga frekansı $(\mathrm{Hz})$ parametreleri ile ölçülmeye çalışılmaktadır. Patlatmalardan kaynaklanan yer titreşimleri kısa süreli (gelip-geçici) ve düzensiz yer hareketleridir. Zemindeki bir parçacığın hareket hızına parçacık hızı (titreșim hızı) denir. Parçacık hızı sıfırdan başlar, en yüksek değerine ulaşır ve giderek sönümlenir. Șu halde yer titreşimi incelemelerinde en önemli özelliklerden biri en yüksek parçacık hızıdır. Cünkü en yüksek hız değeri ne kadar büyük ise yapı ya da zemin de o denli yüksek şiddette sarsılır. Frekans (f) ise, zemindeki bir parçacığın 1 saniyede kaç kez (devir/saniye) titreştiğini gösterir. Frekans, Hertz (Hz) birimi ile ifade edilir. Yer titreșiminin frekansı da en az parçacık hızı kadar önemlidir.

Yer titreșimlerinin frekans özellikleri başlıca iki unsurdan etkilenirler. Bunlar jeoloji ve gecikmeli ateşlemelerde gecikme aralığıdır [4]. Sürekli şikayetlerin çoğunda, parçacık hızı Amerikan standartlarına göre hasar verme eşik değeri olan $12.5 \mathrm{~mm} / \mathrm{s}$ [2] değerinin çok altında olduğu ve hiçbir hasarın meydana gelmediği durumlarda dahi ciddi titreşim hissedildiği yönündeki his ve endişeler tamamen düşük frekans özelliklerinden kaynaklanmaktadır. Çünkü düşük frekanslı dalgaları insanlar kolayca hissedebilirler. Frekans yüksek olduğunda ise, insanların bunları algılaması çok zordur ve bu nedenle fazla endişeye kapılmazlar. Ayrıca $10 \mathrm{~Hz}$ değerinin altındaki frekanslar zeminde büyük yer değişimler ve yüksek düzeyli birim deformasyonlar yarattığı için hasar olasılığını da artırır.

Binalara verilen hasarda, sarsintıların taşıdığı enerji düzeyinin yanı sıra binaların yapım tekniği, boyutları ve 
üzerine oturdukları zemin özellikleri de etkin olmaktadır [2] $\mathrm{Bu}$ nedenlerle sarsintıya bağlı hasar etütlerinde çok kapsamlı çalışmak gerekmektedir.

\subsection{Hasar sınıflandırması}

2.4.1. A.B.D. Madencilik Dairesi Sinıflandırması

A.B.D. Madencilik Dairesi'nin geliștirdiği sınıflamada "Eşik Hasar", "Hafif Hasar" ve "Esaslı Hasar" olmak üzere üç hasar sınıf tanımlanır [2]. Boya ve sivada kılcal çatlakların oluştuğu "eşik hasar" sadece görünüm bozucu niteliktedir. Siva düşmesi, çatlakların $3 \mathrm{~mm}$ ' ye kadar genişlemesi şeklinde görülen "hafif hasar" göreceli olarak daha fazla rahatsız edici olmasına rağmen yapıların dayanımını ve yapı elemanlarının yük taşıma kabiliyetlerini etkilemez. Duvarlarda geniş çatlaklar, duvar ve bacalardan taș, tuğla düşmesi sonucu yapıda kalıcı deformasyonlar oluşturan ve yapıyı zayıflatan tek hasar türü ise "esaslı hasar" sınıfıdır. Çizelge 1'de yapılarda hasar yaratmayacak emniyetli sarsıntı düzeyleri yapı türlerine göre verilmiștir [34].

Çizelge 1. Emniyetli yer sarsıntısı düzeyleri ([34]

\begin{tabular}{|l|c|c|}
\hline \multirow{2}{*}{ Yapı Türü } & \multicolumn{2}{|c|}{$\begin{array}{c}\text { Yer sarsıntıSı en yüksek } \\
\text { parçacık hızı (mm/s) }\end{array}$} \\
\cline { 2 - 3 } & $\begin{array}{c}\text { Düşük } \\
\text { frekans } \\
(<40 \mathrm{~Hz})\end{array}$ & $\begin{array}{c}\text { Yüksek } \\
\text { frekans } \\
(>40 \mathrm{~Hz})\end{array}$ \\
\hline $\begin{array}{l}\text { Modern } \\
\text { Evler }\end{array}$ & 19.0 & 50.8 \\
\hline $\begin{array}{l}\text { Eski Yapılar } \\
\text { (Ahşap } \\
\text { Elemanlı) }\end{array}$ & 12.7 & 50.8 \\
\hline
\end{tabular}

Çizelge 1'de verilen sınır değerler A.B.D.'deki yerinde ölçüm ve gözlemlerde eşik hasar oluştuğu gözlenen düzeylerden daha düşük seçilmiştir. $\mathrm{Bu}$ değerler yüzeysel çatlak oluşum olasılığının en fazla \%5 olabileceğini kabul eder. Diğer bir deyişle yüzeysel çatlak oluşmamasını \%95 oranında garanti eder.

\subsubsection{Türk Hasar Sınıflandırma Kriterleri}

Batılı ülkelerde, hasar oluşmaması için zeminde izin verilen titreşim hızı sınır değerleri, ilgili ülke tüzüklerinde verilmektedir. Ülkemizde ise bu konuda Avrupa Birliği tarafından yayınlanmıs bulunan, 25/6/2002 tarih, 2002/49/EC sayllı Çevresel Gürültünün Yönetimi ve Değerlendirilmesi Direktifine paralel olarak hazırlanmış olan bir yönetmelik, 01 Temmuz 2005 tarihinde 25862 sayllı Resmi Gazetede yayınlanarak yürürlüğe konulmuş bulunmaktadır.

Türk yönetmeliği “ Çevresel Gürültünün Değerlendirilmesi ve Yönetimi Yönetmeliği (CGGYY) başlı̆̆ını taşımakta olup, ülkemizde ilk kez titreșim konusunda bir düzenleme içermektedir.

ÇGDYY Madde 29'da çevresel titreşim esas ve kriterleri belirtilmiș olup, söz konusu Madde 29 aşağıda aynen verilmiştir:

"Yerleşim alanlarında çevresel kaynaklar için titreşim kriterleri

Madde 29- Çeşitli titreşim kaynaklarının neden olacağı çevresel titreşimin kontrol altına alınmasına ilişkin esaslar aşağıda belirtilmiştir:

a) Maden ve taş ocakları ile benzer faaliyette bulunulan alanlardaki patlatmaların çevredeki yapılara zarar vermemesi için, en yakındaki yapının dışında, zeminde ölçülecek titreşim düzeyi Tablo-9 da verilen değeri geçemez (Çizelge 6). Ölçümler üç yönde yapılır ve bunlardan en yüksek olanı alınır. Titreşimler 1/3 oktav bantlarında tepe değeri olarak ölçülür. 
Cizelge 2. CCGDY Madde 29'da Tablo-9: Maden ve Taș Ocakları ile Benzeri Alanlarda Patlama Nedeniyle Oluşacak Titreşimlerin En Yakın Yapının Dıșında Yaratacağı Zemin Titreşimlerinin İzin Verilen En Yüksek Değerleri [35]

\begin{tabular}{|c|c|}
\hline $\begin{array}{c}\text { Titreșim } \\
\text { frekansı (Hz) }\end{array}$ & $\begin{array}{c}\text { İzin verilen en yüksek } \\
\text { titreşim hızı } \\
\text { (tepe değeri- } \mathbf{~ m m} / \mathbf{s} \text { ) }\end{array}$ \\
\hline 1 & 5 \\
\hline $4-10$ & 19 \\
\hline $30-100$ & 50 \\
\hline
\end{tabular}

(1 Hz - $4 \mathrm{~Hz}$ arasında $5 \mathrm{~mm} / \mathrm{s}^{\prime}$ den $19 \mathrm{~mm} / \mathrm{s}^{\prime}$ ye $10 \mathrm{~Hz}-30 \mathrm{~Hz}$ arasinda $19 \mathrm{~mm} / \mathrm{s}^{\prime}$ den $50 \mathrm{~mm} / \mathrm{s}^{\prime} y e$ logaritmik çizilen grafikte doğrusal olarak yükselmektedir)

Türk hasar sınıflandırma kriterlerinden, İnșaat Sektörüne uygun olan grafik Şekil 1 'de gösterilmektedir.

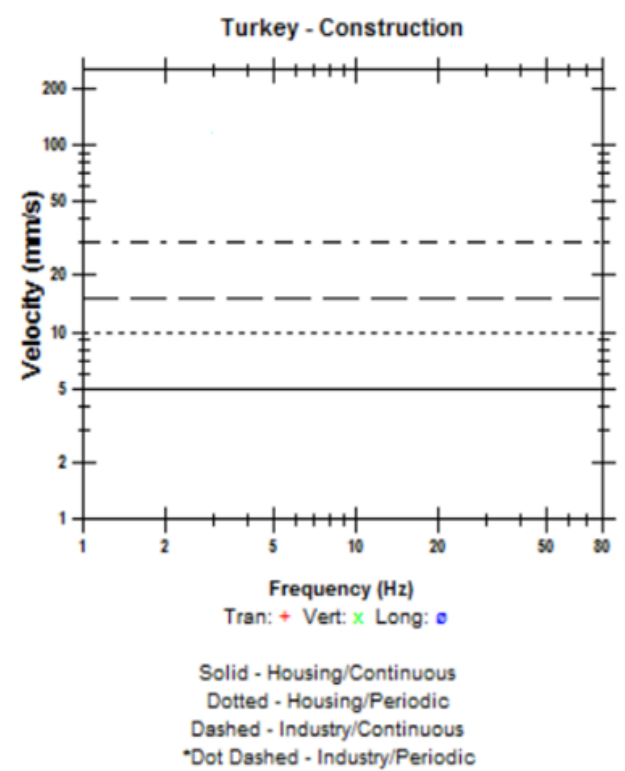

Şekil 1. Türk Hasar sınıflandırma grafiği (İnşaat sektörüne özel)

Şekil 1'den görüleceği üzere, sürekli siyah çizgi mesken yapıları etkileyebilecek sürekli titreşimler söz konusu olduğunda dikkate alınması gereken limit çizgidir. Hemen üzerindeki noktalı çizgi, mesken yapılar periyodik olarak titreşime maruz kaldığında dikkate alınacaktır. Kesikli ve noktalı kesikli çizgiler ise sırasıyla endüstriyel yapılara verilecek sürekli ve periyodik titreşimler söz konusu olduğunda dikkate alınacaktır.

\subsubsection{Alman DIN4150 Normu}

Hasar sinıflandırma kriterleri arasında Alman DIN4150 [36] normu en hassas olanıdır. Alman DIN normu, patlatma kaynaklı titreșimlerin, yapılara hasar vermemesi için izin verilen limit değerlerini, parçacık hızı-frekansa göre 3 farklı renkte oluşturduğu eğrilerin altında kalacak şekilde göstermektedir. Kırmızı çizgi, tarihi eserler sınıfındaki yapılar için izin verilebilecek genliklerin altında kalması gereken eğriyi; yeşil, betonarme yapılar için, mavi ise çok sağlam endüstriyel ve sanayi yapılar için izin verilebilecek genliklerin altında kalması gereken eğriyi göstermektedir. Şekil 2'den de görüleceği üzere, frekans arttıkça izin verilen genlik değerleri yükselmektedir. Çizelge 3, Alman DIN 4150 normuna göre, yapı tiplerine ve frekansa göre izin verilen parçacık hızlarını göstermektedir.

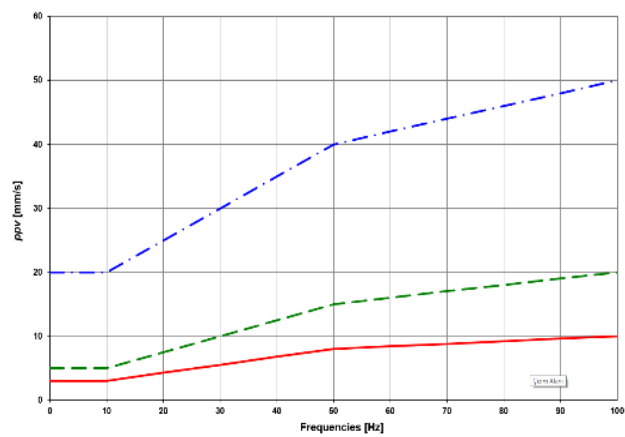

Șekil 2. Alman DIN4150 Hasar Kriteri

Çizelge 3. Alman DIN 4150 normuna göre, yapı tiplerine ve frekansa göre izin verilen parçacık hızları

\begin{tabular}{|c|c|c|c|c|c|}
\hline \multirow[t]{2}{*}{ Sinif } & \multirow[t]{2}{*}{ Yapı Tipi } & \multicolumn{4}{|c|}{$\begin{array}{c}\begin{array}{c}\text { Titresim hizları (ppv) referans değerleri } \\
\text { Yapılara gelen titresimlerin frekans } \\
\text { değerleri }\end{array} \\
\end{array}$} \\
\hline & & $\begin{array}{c}1-10 \\
\mathrm{~Hz}\end{array}$ & $\begin{array}{c}10-50 \\
\mathrm{~Hz}\end{array}$ & $\begin{array}{c}\begin{array}{c}50-100 \\
\mathrm{~Hz}^{*}\end{array} \\
\end{array}$ & $\begin{array}{c}\text { Tüm } \\
\text { frekanslar }\end{array}$ \\
\hline 1 & $\begin{array}{l}\text { Ticari ve endüstriyel, } \\
\text { sanayi yapıları }\end{array}$ & 20 & $20-40$ & $40-50$ & 40 \\
\hline 2 & $\begin{array}{c}\text { Yerleșim yerlerindeki } \\
\text { oturulan binalar } \\
\end{array}$ & 5 & $5-15$ & $15-20$ & 15 \\
\hline 3 & $\begin{array}{c}\text { Tarihi eser gibi özel } \\
\text { koruma altna alınması } \\
\text { gereken hassas yapilar }\end{array}$ & 3 & 3-8 & 8-10 & 8 \\
\hline
\end{tabular}




\section{3. ÇALIŞMA SAHASI}

Çalışma sahası, İzmir ilinde, Yeşildere caddesinden başlayarak Konak Bahribaba Parkına kadar çift tüp olarak planlanan, Yeșildere caddesi girişinden itibaren Eğitim Diş Hastanesi ile Etnoğrafya Müzesi arasında son bulan Konak Tünelleridir. Yaklașik $3290 \mathrm{~m}$ uzunluğundaki tünel, çift tüp olarak tasarlanmıștır. Tünel giriși taban kotu 4.0 metre tünel çıkışı taban kotu ise 48,0 metre olup tünel eğimi yaklaşık \% 2.7'dir. Tünel tabanının geçki ekseni boyunca en derin yeri KM $1+600$ 'da yüzeyden yaklaşık 110 m'dir. Tünel geçkisi boyunca yüzeyde çok yoğun yerleşim alanları bulunmaktadır. Tünel giriș ve çıkışlarının lokasyonları Şekil 3'de verilmektedir.

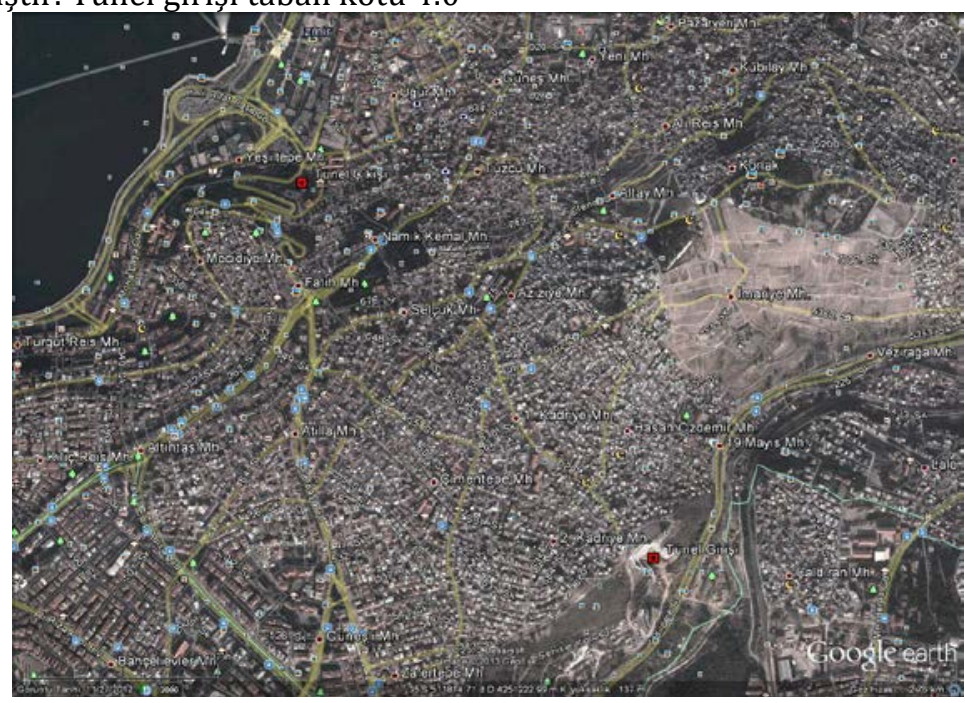

Şekil 3. Tünel giriș ve çıkış lokasyonlarını gösteren google earth görüntüsü

\subsection{Genel Jeoloji}

Çalıșma alanı ve çevresi genel anlamda Anadolu-Toros Bloğunun bir parçası olarak yorumlanan ve Menderes Masifi'nin kuzeybatısında bulunan Bornova Fliş Zonu içinde yer almaktadır $[16,17,18]$. Bornova Fliş Zonu, Paleozoyik ve Erken Tersiyer zaman aralığında Gondwana ve Avrasya (Laurasia) arasında yer alan Tetis Okyanusu'nun (Tethys Ocean) kenetlenme zonu (Izmir-AnkaraErzincan Kenetlenme Zonu) ile Menderes Masifi arasında bulunmaktadır.

Çalıșma alanını Izmir-Ankara-Erzincan boyunca geçmişte etkin olan tektonik hareketlerin ve dalma-batma zonlarının ürünleri olan kayaçlar oluşturmaktadır. Çalışma alanı, Bornova Fliş Zonu üzerinde yer alan Neojen yaşlı tortul kayaçlar ve volkanikler içindedir. Melanjın matriksinden daha yaşlı kireçtaşı mega-olistolitleri Bornova Melanjı'nın matriksi içinde gelişigüzel bir düzen içinde bulunurlar. Bahsedilen kireçtaşları, Altındağ ve yöresinde Işıklar kireçtaşı olarak bilinir [19]. Karmaşığın içerisindeki çakıltaşları kahverengimsi siyah renkli, orta-kalın katmanlı, kumtașı ve kireçtaşı çakıllarından oluşan, ara madde veya tane destekli bir dokuya sahip olup, orta dayanımlıdır. Bornova Karmaşığı çökeliminin hemen sonrasında gelișen tektonizmanın etkisiyle şiddetli deforme olmuş ve ilksel yapısını kaybetmiștir [20]. Neojen yaşlı gölsel tortullar Bornova Melanjı'nın üzerine açısal uyumsuz olarak gelir (Șekil 4). Yamanlar 
volkanitleri de mevcut birimleri uyumsuz olarak örter. Kuvaterner yaşlı alüvyon alanda mevcut tüm birimleri uyumsuz olarak üstler [21]. Tünel geçkisi ve yakın yöresinde Miyosen yaşlı volkanik kayaçlar ile bunlarla eş yaşlı çökelen tortu) kayaçlar bulunmaktadır. Volkanik kayaçlar genellikle. tüf, aglomera ve andezitler ile simgelenirken değişken ayrışma dereceleri ile yüzlekler sunmaktadırlar. Tortul kayaçlar ise genellikle taşlaşma (lithification) sürecinin başında olan, kiltaşı, kumtaşı, çakıltaşı ve silttaşı ile simgelenirler.

Yapılan saha çalışmaları sonucunda, tünelin Yeşildere caddesi girişinden itibaren yaklaşık $55 \mathrm{~m}$ boyunca çamurtaşı, kumtaşı, çakıltaşı ardalanması şeklinde devam eden tünel jeolojisi, bu metrelerden sonra 80 . metrelerde tavanda andezit, taban kısmında tüf birimiyle devam etmekte olup, 150. metrelerden itibaren tamamen andezit içerisinde devam etmekte olduğu görülmüştür. Tünel, Yeşildere caddesi girişinin 150. metresinden itibaren yaklașık 1250. metreye kadar tamamen andezit birimi içerisinde devam etmekte, 1250. metreden sonra çakıltaşı, kiltaşı, silttaşı, kumtaşı ardalanması ile devam etmektedir. Şekil 5'de verilen jeolojik kesitte Yeșildere Caddesi portal girişinin üst kısmında görülen "Yapay Dolgu" Muhtemel Riskli Heyelan Bölgesi, Yapay Dolgu ile Andezit biriminin kesişme yüzeyi ise "Riskli Heyelan Düzlemi" olarak belirlenmiștir [23].

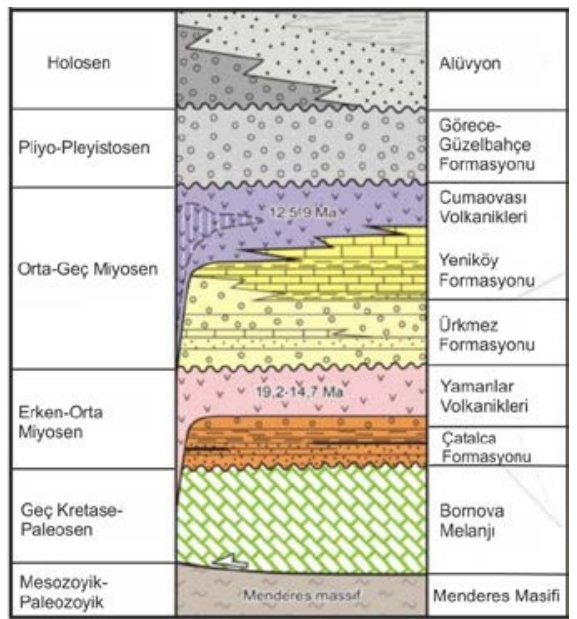

Şekil 4. İzmir körfezi için genelleștirilmiş dikme kesit [22]

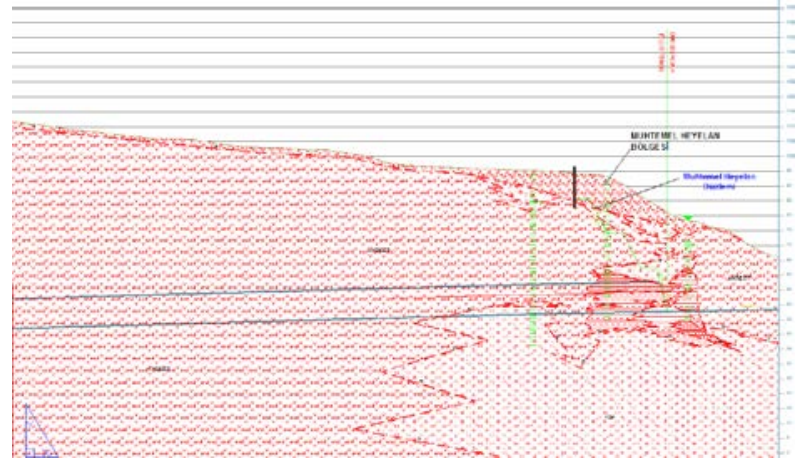

Şekil 5. Yeşildere Caddesi girişinden itibaren gözlenen jeolojik birimler 


\subsection{Jeoteknik Çalışmalar}

\subsubsection{Q Sinıflama Sistemi}

Tünel giriş portalı ve yakın çevresinde açılan sondajlara göre tünel kotunda Alt Tortul Seri'nin çoğunlukla kumtaşı ve kiltaşı birimi kesilmektedir. Tünel üzerindeki örtü kalınlı̆̆ının 100 metreler civarında olduğu bölgelerden tünel çıkışına kadar olan aralıkta andezitik kütlelerin tünel kotunda kesileceği belirlenmiştir. Tünel çıkış portalı ise çoğunlukla tüf, andezit ve bu birimlerle geçişli olan Üst Tortul Seri'nin kumtaşı, kiltaşı ve çakıltaşı birimlerinden oluşmaktadır [23].

Laboratuvar deney sonuçları, tünel kaya sınıflaması ve tünel destek tasarımı çalışmalarının sonuçları genelleştirilmiş biçimi ile Çizelge 4'de verilmektedir.

\subsubsection{RMR Kaya Sinıflaması}

Bilindiği üzere tünel tasarımlarında $Q$ ve RMR görgül kaya sinıflamaları birbirlerini bütünler biçimde birlikte kullanılmaktadır. RMR kaya sınıflaması değerlendirmeleri Çizelge 5'de verilmektedir.
Çizelge 6'da ise, RMR kaya sınıflamasına göre kayaçların kütle özellikleri ve önerilen destek sistemleri verilmektedir.

$\mathrm{Bu}$ sinıflamaya ek olarak, sayısal çözümlemelerde kullanılmak üzere GSI kaya sinıflamasından da yararlanılmıştır. Yapılan GSI değerlendirmeleri tünel tasarım parametreleri ile aynı çizelgede belirtilmiştir [23].

\subsection{3. Q-RMR-NATM \\ Destek}

\section{Önerilerinin Denetimi}

Söz konusu Jeoteknik raporda, Sayısal çözümlemelerde kullanılması önerilen kayaçların jeoteknik parametreleri GSI kaya sinıflaması ile RocLab programı kullanılarak sağlanmış ve sonuçlar Çizelge 7'de verilmiştir.

Çizelge 7'de verilen RMR ve GSI değerleri, bu kaya sinıflamaları ile yapılan özgün değerlendirmelerden elde edilen değerlerdir.

Çizelge 4. Proje Q değerleri [23]

\begin{tabular}{|l|c|c|c|c|c|c|c|c|c|}
\hline $\begin{array}{l}\text { Incelenen } \\
\text { Kesit }\end{array}$ & $\begin{array}{c}\mathrm{RQD}^{(3)} \\
(\%)\end{array}$ & $\mathrm{Jn}$ & $\mathrm{Jr}$ & $\mathrm{Ja}$ & $\mathrm{Jw}$ & $\mathrm{SRF}$ & $\begin{array}{c}\mathrm{H}^{(2)} \\
(\mathrm{m})\end{array}$ & $\begin{array}{c}\mathrm{UCS}^{*} \\
(\mathrm{MPa})\end{array}$ & $\mathrm{Q}$ \\
\hline $\mathrm{T}-\mathrm{Pa}^{(1)}$ & 10 & 12 & 1.5 & 4 & 0.66 & 5.0 & 35 & 10 & 0.04 \\
\hline $\mathrm{T}-50 \mathrm{a}$ & 25 & 6 & 2 & 4 & 0.66 & 5.0 & 50 & 15 & 0.28 \\
\hline $\mathrm{T}-75 \mathrm{a}$ & 10 & 6 & 0.5 & 4 & 0.66 & 2.5 & 75 & 15 & 0.06 \\
\hline $\mathrm{T}-100 \mathrm{a}$ & 10 & 6 & 0.5 & 4 & 0.66 & 2.5 & 100 & 15 & 0.06 \\
\hline $\mathrm{T}-110 \mathrm{a}$ & 10 & 6 & 0.5 & 4 & 0.66 & 2.5 & 110 & 15 & 0.06 \\
\hline $\mathrm{T}-110 \mathrm{~b}$ & 80 & 9 & 3 & 2 & 1.00 & 1.0 & 110 & 45 & 13.3 \\
\hline $\mathrm{T}-100 \mathrm{~b}$ & 50 & 9 & 3 & 2 & 1.00 & 1.0 & 100 & 45 & 8.30 \\
\hline $\mathrm{T}-75 \mathrm{~b}$ & 50 & 9 & 3 & 2 & 1.00 & 2.5 & 75 & 40 & 3.33 \\
\hline $\mathrm{T}-50 \mathrm{~b}$ & 10 & 6 & 1.5 & 4 & 0.66 & 5.0 & 50 & 10 & 0.08 \\
\hline $\mathrm{T}-\mathrm{Pb}$ & 10 & 12 & 2 & 4 & 0.66 & 5.0 & 35 & 10 & 0.06 \\
\hline
\end{tabular}

(1) P: Portal, T: Tünel, a: Tünel giriş portalı tarafi, b: Tünel çıkış portalı tarafinı simgelemektedir.

(2) H:Yeraltı kazısı üzerindeki tabaka kalınlı̆̆ı

(3) RQD değerleri, örtü kalınlığına göre belirlenen tünel aralıklarındaki sondajlarda tünel kotunun 10 $m$ așağısı ve yukarısını kapsayan kesimi değerlendirerek seçilmiştir.

* : Laboratuvar deney sonuçları değerlendirilerek seçilen değerlerdir. 
Küçük ve Aksoy / Şehir İçi Tünel İnşaatlarındaki Kazılarda Patlatma Tasarımı: Konak Tünelleri Örneği

Çizelge 5. Projeye ait RMR değerleri [23]

\begin{tabular}{|l|c|c|c|c|c|c|}
\hline \multirow{2}{*}{$\begin{array}{c}\text { Incelenen } \\
\text { Kesit }\end{array}$} & UCS & RQD & $\begin{array}{c}\text { Süreksizlik } \\
\text { aralığı }\end{array}$ & $\begin{array}{c}\text { Su } \\
\text { koşulları }\end{array}$ & $\begin{array}{c}\text { Süreksizliklerin } \\
\text { durumları }\end{array}$ & \multirow{2}{*}{ RMR } \\
\cline { 2 - 6 } & 1.0 & 3.0 & 5.0 & 4.0 & 17.5 & 30.5 \\
\hline T-Pa & 1.0 & 3.0 & 5.0 & 4.0 & 17.5 & 30.5 \\
\hline T-50a & 2.0 & 3.0 & 5.0 & 4.0 & 17.5 & 31.5 \\
\hline T-75a & 2.0 & 3.0 & 5.0 & 4.0 & 17.5 & 31.5 \\
\hline T-100a & 2.0 & 3.0 & 5.0 & 4.0 & 17.5 & 31.5 \\
\hline T-110a & 4.0 & 8.0 & 8.0 & 12.5 & 19.0 & 51.5 \\
\hline T-110b & 4.0 & 8.0 & 8.0 & 10 & 17.5 & 47.5 \\
\hline T-100b & 4.0 & 8.0 & 8.0 & 8.5 & 15.5 & 44.0 \\
\hline T-75b & 1.0 & 3.0 & 5.0 & 4.0 & 17.5 & 30.5 \\
\hline T-50b & 1.0 & 3.0 & 5.0 & 4.0 & 17.5 & 30.5 \\
\hline T-Pb & & & & & & \\
\hline
\end{tabular}

Çizelge 6. RMR kaya sınıflamasına göre kayaçların kütle özellikleri ve önerilen destek sistemleri [23]

\begin{tabular}{|c|c|c|c|c|}
\hline RMR Aralığı & $64<$ RMR $<85$ & $55<$ RMR $<85$ & $45<\mathrm{RMR}<55$ & $25<$ RMR $<45$ \\
\hline RMR & - & - & $47.5-51.5$ & $30.5-31.5-44.0$ \\
\hline $\begin{array}{lcc}\text { Tek } & \text { Eksenli } & \text { Basınç } \\
\text { Dayanımı (Mpa) } & \\
\end{array}$ & - & - & 40,45 & 5,40 \\
\hline Kohezyon c (Mpa) & - & - & 0.25 & 0.15 \\
\hline İçsel Sürtünme Açısı ( $\phi)$ & - & - & 30 & 20 \\
\hline $\begin{array}{l}\text { Kazılabilecek En Büyük } \\
\text { Açlklık (m) }\end{array}$ & - & - & 6.62 & $3.46-5.91$ \\
\hline Duraylılık Süresi & - & - & 12,5 saat & 1 saat- 7,8 saat \\
\hline $\begin{array}{l}\text { Desteksiz Kazılabilecek } \\
\text { En Büyük Açılılı (m) }\end{array}$ & - & - & 1.85 & $1.0-1.62$ \\
\hline 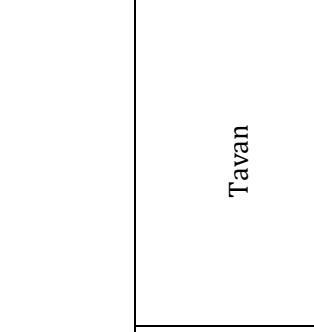 & $\begin{array}{c}\text { Gerektiğinde } 5 \\
\text { cm püskürtme } \\
\text { beton+ } \\
\text { Noktasal bulon } \\
(\phi 20 \mathrm{~L}=3 \mathrm{~m})\end{array}$ & $\begin{array}{c}5-10 \mathrm{~cm} \\
\text { püskürtme } \\
\text { beton+ } \\
\text { Sistematik } \\
\text { Bulon } \\
(\phi 20 \mathrm{~L}=4 \mathrm{~m} \\
\text { aralı } 1.5-2 \mathrm{~m})+ \\
\text { Hasır çelik }\end{array}$ & $\begin{array}{c}5-10 \mathrm{~cm} \\
\text { püskürtme } \\
\text { beton+ } \\
\text { Sistematik } \\
\text { Bulon } \\
(\phi 20 \mathrm{~L}=4 \mathrm{~m} \\
\text { aralık } 1.5-2 \mathrm{~m})+ \\
\text { Hasır çelik }\end{array}$ & $\begin{array}{c}10-15 \mathrm{~cm} \\
\text { püskürtme } \\
\text { beton+ } \\
\text { Sistematik bulon } \\
(\phi 20 \mathrm{~L}=4-5 \mathrm{~m} \\
\text { aralık } 1-1.5 \mathrm{~m})+ \\
\text { Hasır çelik+ } \\
\text { Gerektiğinde } \\
1.5 \mathrm{~m} \text { aralıklı } \\
\text { çelik destek }\end{array}$ \\
\hline 胥 & $\begin{array}{l}\text { Destek } \\
\text { Gerekmez }\end{array}$ & $\begin{array}{c}3 \mathrm{~cm} \\
\text { püskürtme } \\
\text { beton }\end{array}$ & $\begin{array}{c}3 \mathrm{~cm} \\
\text { püskürtme } \\
\text { beton }\end{array}$ & $\begin{array}{c}10-15 \mathrm{~cm} \\
\text { püskürtme } \\
\text { beton+ } \\
\text { Sistematik bulon } \\
(\phi 20 \mathrm{~L}=4-5 \mathrm{~m} \\
\text { aralık } 1-1.5 \mathrm{~m})+ \\
\text { Hasır çelik+ } \\
\text { Gerektiğinde } 1.5 \\
\text { m aralıklı çelik } \\
\text { destek } \\
\end{array}$ \\
\hline
\end{tabular}


Küçük ve Aksoy / Şehir İçi Tünel İnşaatlarındaki Kazılarda Patlatma Tasarımı: Konak Tünelleri Örneği

Çizelge 7. Tünel tasarım parametreleri [23]

\begin{tabular}{|c|c|c|c|c|c|c|c|c|c|c|}
\hline \multirow{2}{*}{$\begin{array}{l}\text { İncelenen } \\
\text { Kesit }\end{array}$} & \multicolumn{2}{|c|}{ PORTAL KESIMİ } & \multicolumn{8}{|c|}{ TÜNEL KESIMMI } \\
\hline & $\mathrm{T}-\mathrm{Pa}$ & $\mathrm{T}-\mathrm{Pb}$ & T-60b & $\mathrm{T}-75 \mathrm{~b}$ & T-100b & $\mathrm{T}-110 \mathrm{~b}$ & T-110a & T-100a & T-75a & T-50a \\
\hline RMR & 30.5 & 30.5 & 30.5 & 43.5 & 47.5 & 51.5 & 31.5 & 31.5 & 31.5 & 30.5 \\
\hline GSI & 25 & 25 & 25 & 50 & 50 & 65 & 30 & 30 & 30 & 30 \\
\hline$Q$ & 0.04 & 0.06 & 0.08 & 3.33 & 8.30 & 13.3 & 0.06 & 0.06 & 0.06 & 0.28 \\
\hline Q Aralığ & $0.01<Q<0.1$ & $0.01<Q<0.1$ & $\begin{array}{c}0.01<Q< \\
0.1\end{array}$ & $1<Q<4$ & $4<Q<10$ & $10<Q<40$ & $0.01<Q<0.1$ & $\begin{array}{c}0.01<Q< \\
0.1\end{array}$ & $0.01<Q<0.1$ & $0.1<Q<1$ \\
\hline E (Mpa) & 180 & 180 & 180 & 1272 & 1388 & 3065 & 366 & 366 & 366 & 366 \\
\hline Poisson 0.v & 0.30 & 0.30 & 0.30 & 0.25 & 0.20 & 0.20 & 0.30 & 0.30 & 0.30 & 0.30 \\
\hline TEBD, $\sigma_{c}(\mathrm{MPa})$ & 10.00 & 10.0 & 10.0 & 40.00 & 45.00 & 45.00 & 15.0 & 15.0 & 15.0 & 15.0 \\
\hline $\begin{array}{l}\text { Örselenme } \\
\text { Etmeni, D* }\end{array}$ & 0.00 & 0.00 & 0.00 & 0.20 & 0.20 & 0.20 & 0.00 & 0.00 & 0.00 & 0.00 \\
\hline$(\gamma)\left(\mathrm{MN} / \mathrm{m}^{3}\right)$ & 0.022 & 0.022 & 0.022 & 0.024 & 0.024 & 0.024 & 0.022 & 0.022 & 0.022 & 0.022 \\
\hline $\mathrm{c}(\mathrm{MPa})$ & 0.092 & 0.092 & 0.116 & 0.505 & 0.628 & 0.959 & 0.250 & 0.235 & 0.196 & 0.152 \\
\hline İçsel Sürt.AçıSı & 39.0 & 39.0 & 36.70 & 58.00 & 54.50 & 57.74 & 35.64 & 36.37 & 38.57 & 41.66 \\
\hline $\begin{array}{c}\text { MR veya (EI) } \\
(\mathrm{MPa})\end{array}$ & 300.00 & 300.00 & 300.00 & $\begin{array}{c}(5500 \\
)\end{array}$ & (6000) & $(6000)$ & 300.00 & 300.00 & 300.00 & 300.00 \\
\hline $\mathrm{mi}$ & 12.00 & 12.00 & 12.00 & 25.00 & 25.00 & 25.00 & 12.00 & 12.00 & 12.00 & 12.00 \\
\hline $\mathrm{mb}$ & 0.824 & 0.824 & 0.824 & 3.438 & 3.438 & 6.234 & 0.985 & 0.985 & 0.985 & 0.985 \\
\hline si & 1.00 & 1.00 & 1.00 & 1.00 & 1.00 & 1.00 & 1.00 & 1.00 & 1.00 & 1.00 \\
\hline $\mathrm{s}$ & 0.0002 & 0.0002 & 0.0002 & $\begin{array}{c}0.002 \\
8\end{array}$ & 0.0026 & 0.0155 & 0.0004 & 0.0004 & 0.0004 & 0.0004 \\
\hline$a$ & 0.531 & 0.531 & 0.531 & 0.508 & 0.508 & 0.502 & 0.522 & 0.522 & 0.522 & 0.522 \\
\hline $\begin{array}{c}\text { Etkin Kaya } \\
\text { Yüksekliği, h (m) }\end{array}$ & 35.00 & 35.00 & 50.00 & 75.00 & 100.00 & 110.00 & 110.00 & 100.00 & 75.00 & 50.00 \\
\hline $\begin{array}{l}\text { Önerilen Destek } \\
\text { Sınıfı }\end{array}$ & VI & vi & VI & IV & III & II & VI & VI & VI & V \\
\hline
\end{tabular}

4. CALIȘMA UYGULANMASI

\section{PATLATMA PATERNI}

$\mathrm{Bu}$ çalışmada, Konak Tünelleri için, patlatmalı kazı sırasında arzu edilen teknik sonuçların ekonomik ve emniyetli limitlerde, patlatmadan kaynaklanan titreşim ve hava şoku gibi çevresel problemlerin en aza indirilmesine ve dolayısıyla çevre yapılarda bir hasara neden olmayacak, aynı zamanda olası heyelan bölgesinde var olan hareketlerin artmasina izin vermeyecek bir yaklaşımla ön tasarımı yapılmaya çalışılmıştır. İlk oluşturulan patlatma paterninde orta çekme ve kazı deliklerinin bazılarında gecikme başına 9 kg patlayıcı düștüğü belirlenmiștir.

Çalışma sahasının konumu, civar yapılar ve daha önceki imalatlardan hasar görmüş olan binaların ve tünelin Yeşildere giriş portalının bulunduğu bölgedeki olası heyelanın hareketinde bir artışın olabileceği ihtimali nedeniyle orta çekmenin, 6 delikli olarak planlanması ve gecikme başına $6 \mathrm{~kg}$ patlayıcı kullanılmasının daha doğru olacağı tespit edilmiştir. Burada amaç, tünelin bulunduğu yerin yukarıda bahsedilen özellikleri nedeniyle tam bir kazı yapılamasa bile, tünel aynasındaki kaya 
kütlesinin örselenmesini sağlamak ve dolayısıyla makineli kazıdaki güçlükleri bir miktar azaltabilmektir.

Şekil 6'da görüldüğü üzere, $46 \mathrm{~m}^{2}$ tünel üst yarısı için 87 adet delik planlanmıştır. Bunlardan 26 adeti çektirme için planlanan, diğer delikler kazı ve çevre delikleridir. Bu deliklerin 14 adeti 1 . pergel, 14 adeti 2 . pergel, 18 adeti 3 . pergel, 13 adeti taban ve 2 adeti taban köşe deliği olarak planlanmıştır. $\mathrm{Bu}$ deliklerin özellikleri Çizelge 8'de verilmektedir. Olușturulan bu paternde gecikme başına en fazla $6 \mathrm{~kg}$ patlayıcı planlanmıștır.

Delik uzunluğu 1,8 m olacak șekilde yapılacak imalat sonrası toplamda $69 \mathrm{~m}^{3}$ kaya kütlesinin parçalanması planlanmıştır. Toplamda $75.9 \mathrm{~kg}$ patlayıcı ile $69 \mathrm{~m}^{3}$ lük bir kaya kütlesinin örseleneceği düșünüldügünde özgül șarj oranı $1.1 \mathrm{~kg} / \mathrm{m}^{3}$ olarak hesaplanmıştır. Deliklerden orta çekme delikleri 60 derece, tarama delikleri 90 derece ve çevre delikleri dişa doğru 3 derecelik bir açı ile planlanmıştır.

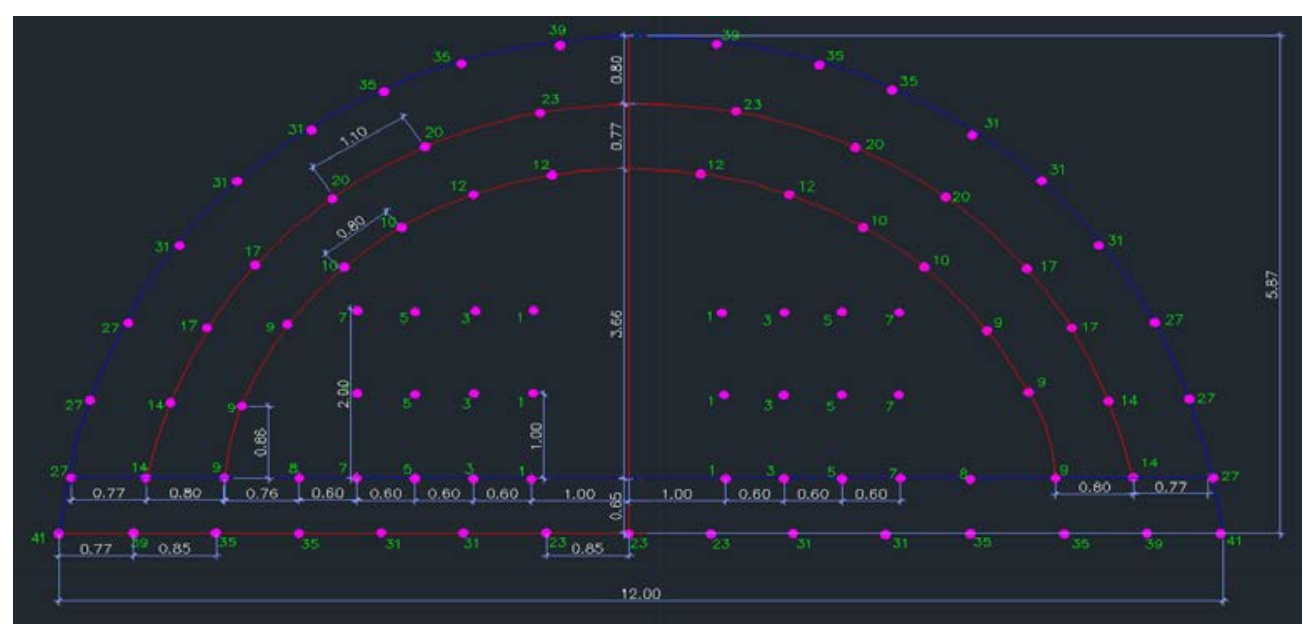

Şekil 6. Tünelde belirlenen patlatma paterni

Çizelge 8. Tasarımı yapılan patlatmaya yönelik 1 atımdaki patlayıcı madde tüketimi (üst yarı)

\begin{tabular}{|c|c|c|c|c|c|c|c|c|}
\hline $\begin{array}{c}\text { Delgi } \\
\text { Yeri }\end{array}$ & $\begin{array}{c}\text { Gecikme } \\
\text { No }\end{array}$ & $\begin{array}{c}\text { Delik } \\
\text { Sayıs } \\
\text { (Adet) }\end{array}$ & $\begin{array}{c}\text { Delik } \\
\text { Boyu } \\
\text { (m) }\end{array}$ & $\begin{array}{c}\text { Deliğe } \\
\text { Sarjlanan } \\
\text { Kartuş } \\
\text { (adet/delik) }\end{array}$ & $\begin{array}{c}\text { Bir } \\
\text { Kartuşun } \\
\text { Ağırlığ } \\
\text { (kg) }\end{array}$ & $\begin{array}{c}\text { Delik } \\
\text { Başına Şarj } \\
\text { (kg/delik) }\end{array}$ & $\begin{array}{c}\text { Toplam } \\
\text { Sarj } \\
\text { (kg) }\end{array}$ & $\begin{array}{c}\text { Toplam } \\
\text { Delik } \\
\text { Boyu } \\
\text { (m) }\end{array}$ \\
\hline Kesme & 1 & 6 & 1.8 & 2 & 0.5 & 1 & 6 & 10.8 \\
\hline Kesme & 3 & 6 & 1.8 & 2 & 0.5 & 1 & 6 & 10.8 \\
\hline Kesme & 5 & 6 & 1.8 & 2 & 0.5 & 1 & 6 & 10.8 \\
\hline Kesme & 7 & 6 & 1.8 & 2 & 0.5 & 1 & 6 & 10.8 \\
\hline Kesme & 8 & 2 & 1.8 & 3 & 0.5 & 1.5 & 3 & 3.6 \\
\hline Üretim & 9 & 6 & 1.8 & 2 & 0.5 & 1 & 6 & 10.8 \\
\hline Üretim & 10 & 4 & 1.8 & 2 & 0.5 & 1 & 4 & 7.2 \\
\hline Üretim & 12 & 4 & 1.8 & 2 & 0.5 & 1 & 4 & 7.2 \\
\hline Üretim & 14 & 4 & 1.8 & 2 & 0.5 & 1 & 4 & 7.2 \\
\hline Üretim & 17 & 4 & 1.8 & 2 & 0.5 & 1 & 4 & 7.2 \\
\hline Üretim & 20 & 4 & 1.8 & 2 & 0.5 & 1 & 4 & 7.2 \\
\hline
\end{tabular}


Küçük ve Aksoy / Şehir İçi Tünel İnşaatlarındaki Kazılarda Patlatma Tasarımı: Konak Tünelleri Örneği

Çizelge 8 (Devamı). Tasarımı yapılan patlatmada 1 atımdaki patlayıcı tüketimi (üst yarı)

\begin{tabular}{|c|c|c|c|c|c|c|c|c|}
\hline Üretim & 23 & 2 & 1.8 & 2 & 0.5 & 1 & 2 & 3.6 \\
\hline Tavan & 27 & 2 & 1.8 & 2 & 0.5 & 1 & 2 & 3.6 \\
\hline Tavan & 27 & 4 & 1.8 & 1 & 0.15 & 0.15 & 0.6 & 7.2 \\
\hline Tavan & 31 & 6 & 1.8 & 1 & 0.15 & 0.15 & 0.9 & 10.8 \\
\hline Tavan & 35 & 4 & 1.8 & 1 & 0.15 & 0.15 & 0.6 & 7.2 \\
\hline Tavan & 39 & 2 & 1.8 & 1 & 0.15 & 0.15 & 0.3 & 3.6 \\
\hline Taban & 23 & 3 & 1.8 & 3 & 0.5 & 1.5 & 4.5 & 5.4 \\
\hline Taban & 31 & 4 & 1.8 & 3 & 0.5 & 1.5 & 6 & 7.2 \\
\hline Taban & 35 & 4 & 1.8 & 3 & 0.5 & 1.5 & 6 & 7.2 \\
\hline Taban & 39 & 2 & 1.8 & 3 & 0.5 & 1.5 & 3 & 3.6 \\
\hline Taban köșe & 41 & 2 & 1.8 & 3 & 0.5 & 1.5 & 3 & 3.6 \\
\hline Toplam & & $\mathbf{8 7}$ & & & & & $\mathbf{7 5 . 9}$ & $\mathbf{1 4 9 . 4}$ \\
\hline
\end{tabular}

\subsection{Veri Analizi Ve Değerlendirmeler}

Patlatma tasarımında belirlenen delik geometrileri, patlayı miktarları, gecikmeler...vb. paramatreler önceki tecrübeler ve yapılmış çalışmalara göre oluşturulmuştur. Belirlenen tasarım parametreleri, Seisblast programına [37] girilerek patlatma modellemesi yapılmıştır.

Yapılan modellemede, patlatma yapılan lokasyon ile etkilenebileceği düşünülen yerleșim alanı arasındaki mesafeler 90 ve 170 metre olarak alınmıştır. Buna göre modelleme sonucunda elde edilen maksimum titreşim hızları, ve frekansları hesaplanmıștır (Çizelge 9). Patlatma tasarım değerlerinin modellemesinden elde edilen sonuçlar, Türk-İnşaat Sektörüne göre uyarlanmış hasar kriter çizelgesi ve hassas Alman DIN 4150 normuna göre değerlendirilmiştir.

Çizelge 9. Modelleme sonucunda patlatma kaynaklı oluşabilecek titreşim değerleri

\begin{tabular}{|c|c|c|c|}
\hline \multirow{2}{*}{$\begin{array}{c}R \\
(\mathrm{~m})\end{array}$} & \multicolumn{3}{|c|}{$\begin{array}{l}\text { Maksimum Oluşabilecek Titreşim Hızı ve } \\
\text { Frekansı }\end{array}$} \\
\hline & Yanal & Düșey & Boyuna \\
\hline 170 & $\begin{array}{c}1.230 \mathrm{~mm} / \mathrm{s} \\
19 \mathrm{~Hz}\end{array}$ & $\begin{array}{c}0.788 \mathrm{~mm} / \mathrm{s} \\
34 \mathrm{~Hz}\end{array}$ & $\begin{array}{l}0.560 \mathrm{~mm} / \mathrm{s} \\
15.25 \mathrm{~Hz}\end{array}$ \\
\hline 90 & $\begin{array}{l}2.491 \mathrm{~mm} / \mathrm{s} \\
21 \mathrm{~Hz}\end{array}$ & $\begin{array}{c}2.483 \mathrm{~mm} / \mathrm{s} \\
22 \mathrm{~Hz}\end{array}$ & $\begin{array}{c}5.714 \mathrm{~mm} / \mathrm{s} \\
21 \mathrm{~Hz}\end{array}$ \\
\hline
\end{tabular}

R: Patlatma yapılan yer ile sismograf arasindaki mesafe - Yanal, Düşey, Boyuna: Sismik dalganın 3 bileşenidir.
Çizelge 9 incelendiğinde, düșey yönde oluşan maksimum parçacık hızlarının nispeten daha düşük olduğu gözlenmiştir. Yapılan ölçüm çalışmalarının çok büyük çoğunluğu tünel patlatmalarında sarsıntının en fazla hissedildiği yerin, tünel aynasının üstünde düşey yönde bulunan yerleşim birimlerinin olduğu yerler olduğunu göstermiştir.

Şekil 7 ve 8, sırasıyla Türk ve Alman standartlarına göre, modellemeye göre patlatmadan kaynaklanabilecek dalgaların 170 metre ve 90 metredeki ölçülen titreșim hızlarının frekansa bağlı olarak durumunu göstermektedir. Şekil 7 ve 8'de görüleceği üzere, titreșim genliklerinin yüksek frekanslara göre değerlendirilmesini gerekli kılmaktadır ki bu da, izin verilen titreşim hızlarının daha yüksek olmasına sebebiyet vermektedir.

Yapılan patlatma tasarımı ve Seisblast programindaki modellemede, her iki standarda göre de, titreşim hızları, endüstriyel-inşaat yapılarına göre değerlendirildiğinde, izin verilen limit değerler altında kalmaktadır.

Şekil 7'de görüldüğü üzere, yapılacak patlatmada ölçülmesi muhtemel titreşim 
değerleri, noktalı-kesikli çizginin altında kalmaktadır

(periyodik olarak inşaat/endüstriyel yapılara verilen titreşimlerin değerlendirileceği sınır çizgi). Ancak Türk -Endüstriyel/İnşaat yapıları için hazırlanmıș bu standartta, titreșim hızlarının tüm frekanslar için aynı değerlendirildiği görülmektedir. Üstelik kesikli-noktalı çizgi esas alındığında, izin verilebilen titreșim hızları $30 \mathrm{~mm} / \mathrm{s}^{\prime}$ nin üzerinde olacaktır.

Her ne kadar modellemede yapılan patlatma, Türk standatlarına göre bu izin verilen maksimum değerin çok çok altında titreşimlere sebep olsa da, literatüre göre en hassas ve güvenilir hasar kriter skalası olan Alman DIN4150 normuna göre de değerlendirme yapılması uygun görülmüştür.

Şekil 8 incelendiğinde, modellenen patlatmadan kaynaklanacak dalgaların frekans içeriğinin $5-35 \mathrm{~Hz}$ arasında değișeceği ve verilerin hasar verme limitlerinin altında olacağı görülmektedir
(En üst eğri, endüstriyel/inşaat yapıları için oluşturulduğundan dolayı, bu eğri esas alınmıștır).

Cihazların konulacağı noktaların titreșime maruz kalma süreleri de, en az titreșim genlikleri ve frekansları kadar önemlidir.

Veriler incelendiğinde, 170 metrede ve 90 metrede kaydedilecek titreşim sürelerinin, yapılan tasarım ve modelleme neticesinde 1.5 saniyeyi geçmeyeceği görülmüștür. Titreșime maruz kalma süresinin en fazla 2 saniye civarında olacağı belirlenmiş olup, bu özelliklerdeki titreşimlerin yapılara hasar vermediği bilinmektedir.

Şekil 9, modellemeye göre belirlenen, yapılacak patlatmadan kaynaklanacak titreşimlerin 170 metre mesafede ölçülebilecek sürelerini göstermekte olup, sonuçta oluşabilecek titreşim sürelerinin 1.5-2 saniyeyi geçmeyeceği görülmektedir.

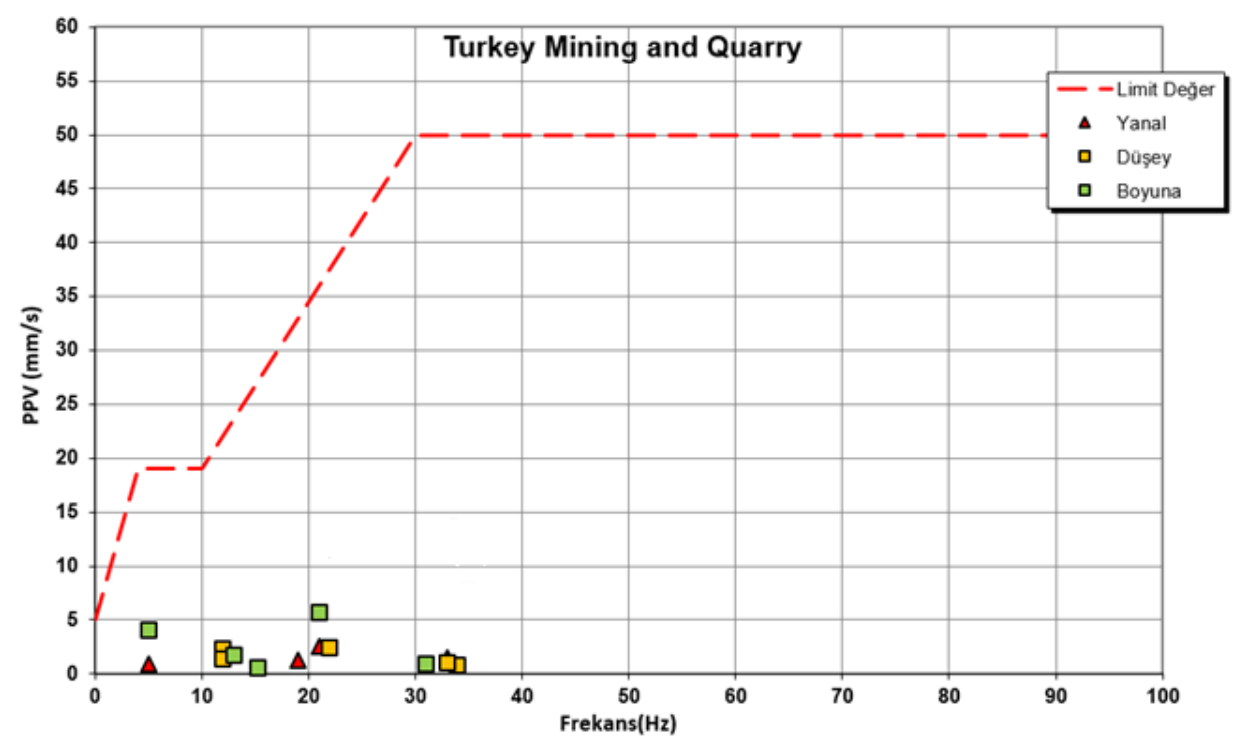

Şekil 7. Modellemeye göre patlatmadan kaynaklanacak titreșimlerin frekansa bağlı olarak Türk-İnşaat sektörüne göre düzenlenmiş skalaya göre değerlendirildiği standart 
Küçük ve Aksoy / Şehir İçi Tünel İnşaatlarındaki Kazılarda Patlatma Tasarımı: Konak Tünelleri Örneği

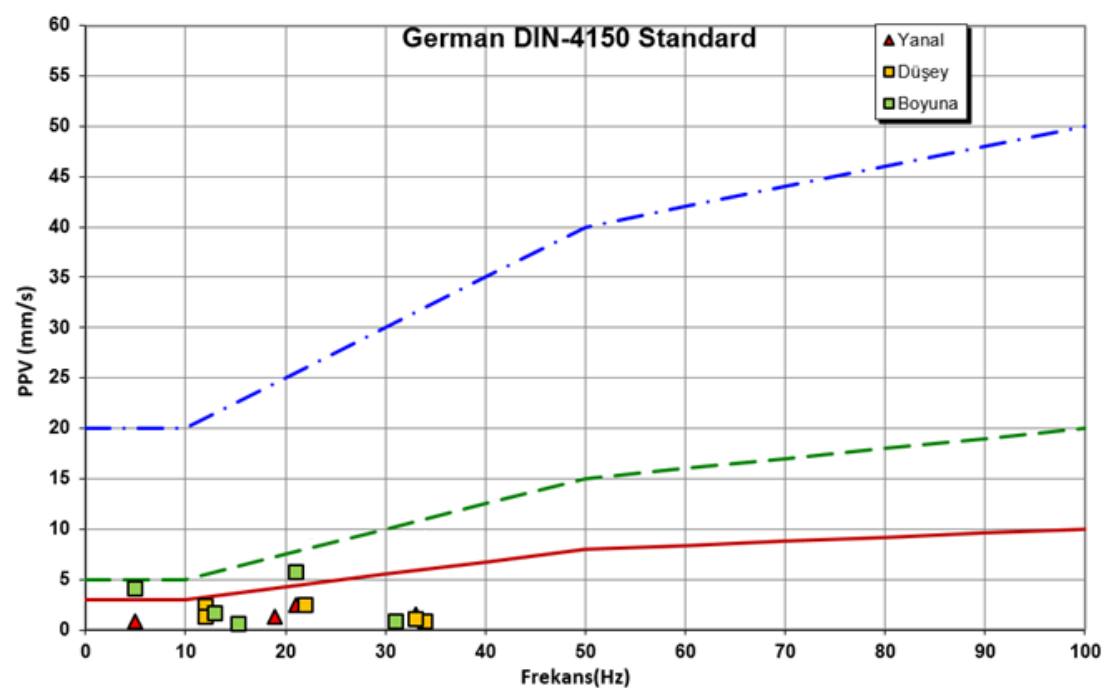

Şekil 8. Modellemeye göre patlatmadan kaynaklanacak titreşimlerin frekansa bağlı olarak, Alman DIN4150'ye göre düzenlenmiş skala ile değerlendirildiği standart

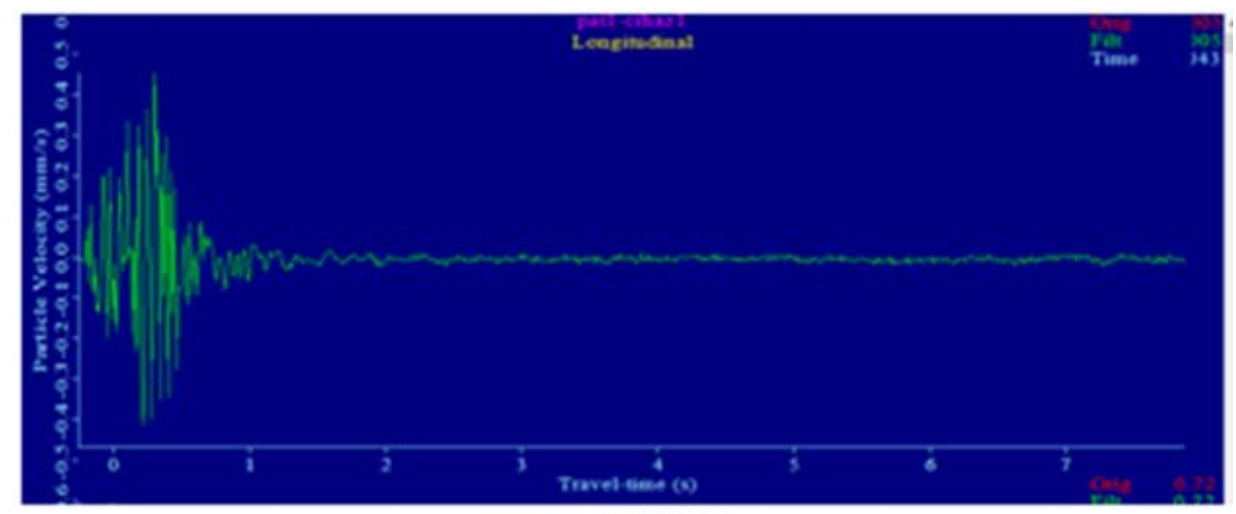

(a) Patlatma (170 m)

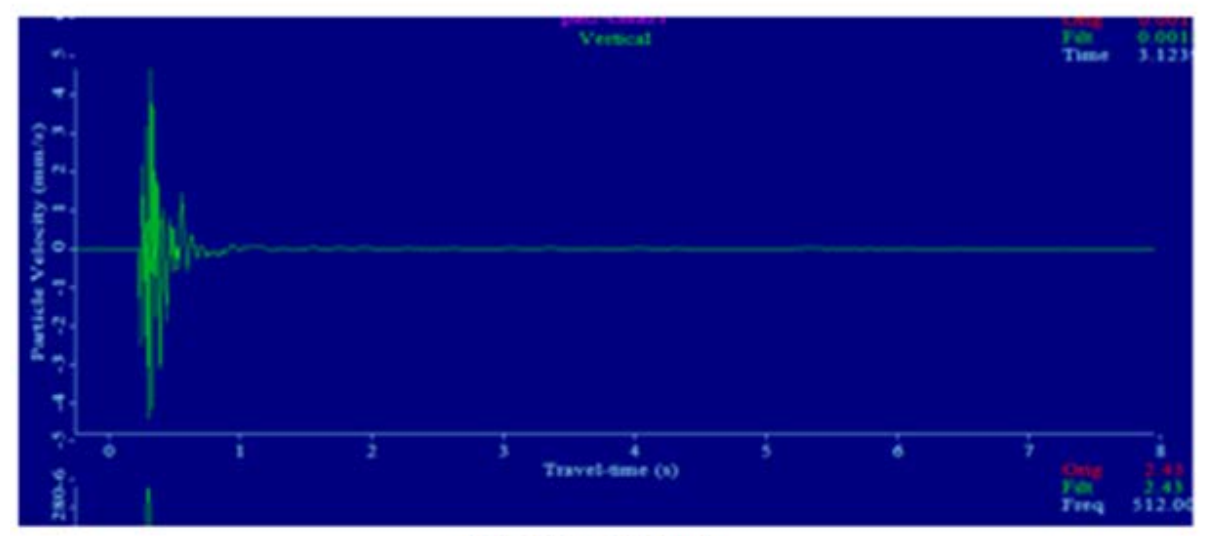

(b) Patlatma ( $90 \mathrm{~m}$ )

Şekil 9. Modellemeye göre belirlenen patlatma kaynaklı oluşabilecek titreşim süreleri 


\section{SONUÇ VE DEĞERLENDIRME}

Söz konusu tünelde yapılacak patlatmaların çevre yapılara olabilecek titreşim etkisi, titreşim ölçümleri sonucu alınan veriler ışığında ilgili standartlar çerçevesinde değerlendirilmiştir.

Belirlenen patlatma tasarım parametreleri ve patlatma modellemesi sonucunda elde edilen veriler ışı̆̆ında, patlatmadan kaynaklanabilecek olası titreşimler, Türk-İnşaat Sektörüne göre uyarlanmış hasar kriter çizelgesi ve hassas Alman DIN 4150 normuna göre değerlendirilmiştir. Her iki standarda göre de, titreşim hızları, endüstriyelinşaat yapılarına göre değerlendirildiğinde, izin verilen limit değerler altında kalmaktadır.

Modellemeye göre, $170 \mathrm{~m}$ ve $90 \mathrm{~m}$ mesafeye konulacak cihazların titreșime maruz kalma süreleri de, en az titreșim genlikleri ve frekansları kadar önemlidir.

Bu sebeple, elde edilen veriler, titreșime maruz kalma süreleri açısından da incelenmiştir. Modellemede, 170 metre ve 90 metre mesafelerde kaydedilebilecek titreşim sürelerinin 1.5 saniyeyi geçmeyeceği görülmüştür. Yapıları uzun süreli titreşime maruz bırakıp hasar vermemek adına, titreşime maruz kalma süresinin 2 saniyeyi geçmemesine dikkat edilmesi gerekliliği literatüre göre de bilindiği için, bu tasarım ve modellemede belirlenen titreşime maruz kalma süresi makul olarak değerlendirilmiştir.

Şekil 6 ve Çizelge 7'de hazırlanan patlatma tasarımı parametrelerine uygun şekilde yapılacak atımların oluşturacağı titreșim hızları ve frekanslarının (Seisblast programı yardımıyla hesaplanan) izin verilen limit değerler içerisinde kalmasına karşın, yerleşim birimlerinin yakınlığı ve heyelan oluşum riski göz önüne alındığında, ilk tünel patlatmalarından itibaren atımlara eşlik edilerek patlatma tasarımı ve çevresel

etkileri konusunda uzman kişilerce titreşim ölçümlerinin alınması, gerekmesi durumunda hazırlanan patlatma tasarımının güncellenmesi, çalışmanın sağlıklı ve güvenli bir şekilde tamamlanabilmesi açısından önem arz etmektedir.

\section{KAYNAKCA}

[1] Bollinger, G.A. 1971. Blast Vibration Analysis. Southern Illinois University Press: 132, Carbondale and Edwardsville, DOI: $10.1093 /$ gji/ 63.3.799a

[2] Siskind, D.E., Stagg, M.S., Kopp, J.W., Dowding, C.H. 1980. Structure response and damage produced by ground vibrations from surface mine blasting. USBM RI 8507: 77, Boston.

[3] Anderson, D.A., Winzer, S.R., Ritter, A.P. 1982. Blast design for optimizing fragmentation while controlling frequency of ground vibration. Proceedings of the 8th Conference on Explosives and Blasting Technique. Proceeding Book: 69-89 1982, New Orleans.

[4] Dowding, C.H. 1985. Blast Vibration Monitoring and Control. Prentice-Hall, Inc.: 297, Englewood Cliffs, NJ.

[5] Siskind, D.E., Crum, S.V., Otterness, R.E., Kopp, J.W. 1989. Comparative study of blasting vibrations from Indiana surface coal mine. USBM RI 9226: 41, Boston.

[6] Anderson, Douglas, 1993. Blast monitoring: regulations, methods and control techniques. Comprehensive Rock Engineering, Vol. 4, pp. 95-110. Editor-in-Chief John Hudson. Pergamon Press Ltd. DOI: 10.1016/B978-0-08-0420677.50011-8

[7] Persson, P.A., Holmberg, R., Lee, J. 1994. Rock Blasting and 
Explosives Engineering. CRC Press, Inc.:367, New York. ISBN 9780849389788

[8] Muller, B. 1997. Adapting blasting technologies to the characteristics of rock masses in order to improve blasting results and reduce blasting vibrations. Fragblast 1: 361-378.DOI: $10.1080 /$ 13855149709408403

[9] Muller, B., Hohlfeld, T.h. 1997. New possibility of reducing blasting vibrations with an improved prognosis. Fragblast 1: 379-392.

[10] Hoshino, T., Mogi, G., Shaoquan, K. 2000. Optimum delay interval design in delay blasting. Fragblast - International Journal of Blasting and Fragmentation 4:139-148.

[11] Siskind, D.E. 2000. Vibrations from Blasting. International Society of Explosives Engineers: 120 pages, New York.

[12] Chen, G., Huang, S. 2001. Analysis of ground vibrations caused by open pit production blasts: a case study. Fragblast-International Journal of Blasting and Fragmentation 5 (1), 91-107. DOI: 10.1076/frag.5.1.91.3316

[13] Tripathy, G. and Gupta, I.D. 2002. Prediction of ground vibrations due to construction blasts in different types of rock. Rock Mechanics and Rock Engineering 35 (3): 195-204. DOI:10.1016/j.jrmge.2015.10.007

[14] Adhikari, G.R., Theresraj, A.I., Venkatesh, S., Balachander, R., Gupta, R.N. 2004. Ground vibration due to blasting in limestone quarries. Fragblast International Journal of Blasting and Fragmentation 8 (2): 85-94. DOI:10.1080/1385514041233133 6160

[15] Kahriman, A., İșlek, A., Erol, A.K., Sefer, İ., (2008), İstanbul SarıyerÇayırbaşı Karayolu Tünel İnşaatı
Patlatmalı Kazı Ön Tasarımı, T.C. Okan Üniversitesi, Mühendislik Fakültesi

[16] Şengör, A.M.C., (1984) The Cimmeride orogenic system and the tectonics of Eurasia Geol. Soc. Am. Spec. Paper, No 19582 pp

[17] Okay, A.I., Tüysüz O. (1999) Tethyan sutures of northern Turkey İTÜ Eurasian Institute of Earth Sciences And Maden Faculty Geological Department

[18] Okay, A.I Satır M., Maluski, H. Siyako, M., Monie, P., Metzger, R. and Akyüz S. (1996) Palen- and Neo-Tethyan events in northwest Turkey Geological and geochroindiogical constraints. In: $\mathrm{A}$ Yin and $\mathrm{M}$ Harrison (Eds), Tectonics ol Asia. Cambridge University Press: 420-441

[19] Özer, S., İrtem, O, (1982), IşıklarAltındağ (Bornova-İzmir) alanı Üst Kretase kireçtaşlarının jeolojik konumu, stratigrafisi ve fasiyes özellikleri, Türkiye Jeoloji Bülteni, 25/1, 41-47.

[20] Erdoğan, B. (1990). İzmir-Ankara Zonu'nun İzmir ile Seferihisar Arasındaki Bölgede Stratigrafik Özellikleri ve Tektonik Evrimi: TPJP Bülteni. c. 2/1-Aralık, 1990. s.1-20.

[21] Gürler, M., (2015), “İzmir Metropol Alanında Mühendislik Ana Kayasının Jeofizik Çalışmalarla Araştırılması", D.E.Ü. FBE Doktora Tezi

[22] Uzel, B., Sözbilir, H., Özkaymak, Ç., Kaymakçı, N., ve Langeris, C. G., 2012. İzmir Körfezi'nin Jeolojik Evrimi, Batı Anadolu. Ali Koçyiğit Çalıştayı Bildiri Özleri Kitapçığı s. 30. 25-26 Haziran ODTÜ Jeoloji Mühendisliği Bölümü, Ankara.

[23] Konak Tüneli ve Bağlantı Yolu Tünel Jeolojik-Jeoteknik Etüt Raporu (2012)

[24] Ak, H., İphar, M., Yavuz, M. and Konuk, A. (2009), Evaluation of 
ground vibration effect of blasting operations in a magnesite mine. Soil Dynamics and Earthquake Engineering. Vol.29, 669-676. DOI:10.1016/j.soildyn.2008.07.00 3

[25] Zhang,Y.H., Lin,J.H., Willams,F.W., Li, Q.S. (2006), Wave passage effect of seismic ground motions on the response of multiply supported structures, Struct. Eng. Mech., 20(6), 655

[26] W.M. Ewing, W.S. Jardetzky, F. Press. Elastic waves in layered media. Mc Graw-Hill Book Co. New York. 1957.

[27] Constantopoulos, I.V., Wessem, V.Y. and Verbrugge, J.C. (2012), Vertical response spectra for an impact on ground surface, Eartq. Struct. 3 (3-4), 435-455.

DOI:10.12989/eas.2012.3.3_4.435

[28] Mahmoud,S. (2014), Blast load inducedresponse and the associated damage of buildings considering SSI, Earthq. Struct., 7(3), 231-252, DOI: 10.12989/eas.2014.7.3.349

[29] Öncü, M.E., Yon,B., Akkoyun,O.and Taskiran,T. (2015), Investigation of blast-induced ground vibration effects on rural buildings, Struct. Eng. Mech., 54(3), 545 DOI:10.12989/sem.2015.54.3.545

[30] Xuelong L., Enyuan W., Zhonghui L., Xiaofei B., Liang C., Junjun F., Nan L., (2016), Blasting wave pattern recognition based on Hilbert-Huang transform Geomechanics and Engineering, Vol. 11, No. 5, 607-624

DOI : 10.12989/gae.2016.11.5.607

[31] Uyar G.G Babayigit E. (2016), Guided wave formation in coal mines and associated effects to buildings Structural Engineering and Mechanics, Vol. 60, No. 6 (2016) 923-937 DOI: $10.12989 /$ sem.2016.60.6.923
[32] Kılıç, A. ve Anıl, M., 2000. Tarsus Ayrımı-Adana-Gaziantep Otoyolu T2 (Ayran) Tünelinde Kaya Sınıflarına Bağlı Kazı ve Tahkimat Uygulamaları, Madencilik Dergisi. Cilt. 39, Sayı. 2, s. 3-10.

[33] Dağçimen, A. (2006), Patlatma Tasarımı İçin Geliștirilen Bir Bilgisayar Programı, Çukurova Üniversitesi Fen Bilimleri Enstitüsü, Yüksek Lisans Tezi

[34] David E. Siskind, Steven V. Crum, and Matthew N. Plis (1993) RI 9455Blast Vibrations and other Potential Causes of Damage in Homes near a Large Surface Coal Mine in Indiana

[35] ÇGYDD, 2005, "2002/49/EC sayılı Çevresel Gürültünün Yönetimi ve Değerlendirilmesi Direktifine paralel olarak hazırlanmış olan bir yönetmelik".

[36] DIN 4150-3, (1999) Structural vibration-Effects of vibration on structures. Deutsches Institut für Normung e. V. Document Number:din 4150-3

[37] Aldaş, G.G.U., Ecevitoglu, B. (2007), "Methodology for Minimizing Blast-Induced Vibrations (TPI. 2007/03459) 